\title{
Transformational Leadership Practices among Academic Administrators at a Public University in Malaysia
}

\author{
Norsamsinar Samsudin ${ }^{\mathrm{a}}$, Ahmad Zainal Abidin Abd. Razak ${ }^{\mathrm{b}}$, Norasibah Abdul Jalil ${ }^{\mathrm{c}}$, \\ Hariyaty Ab. Wahid ${ }^{\mathrm{d}}$, Kamarul Bahari Yaakub ${ }^{\mathrm{e}}$ \\ ${ }^{a}$ Faculty of Management \& Economics, Sultan Idris Education University, Malaysia, \\ norsamsinar@fpe.upsi.edu.my
}

\begin{abstract}
This study aimed to investigate the practice of transformational leadership among academic administrators of a faculty at one of the public universities in Malaysia. Further, this study measured the level of leadership outcomes namely extra effort, effectiveness, and satisfaction. This study used all its population in the faculty, which consists of 71 full-time academicians. The MLQ 5X-Short was utilized as an instrument used to obtain the data. Academicians perceived their academic administrators' leadership style as transformational $(\mathrm{M}=2.42$, $\mathrm{SD}=.55)$. The most practiced leadership style was inspirational motivation $(\mathrm{M}=2.72, \mathrm{SD}=.60)$, followed by idealized influence (behavior) $(\mathrm{M}=2.60, \mathrm{SD}=.63)$ and idealized influence (attributed) $(\mathrm{M}=2.42, \mathrm{SD}=.64)$. The least frequent types of leadership styles were individual consideration $(\mathrm{M}=2.05, \mathrm{SD}=.65)$, and intellectual stimulation $(\mathrm{M}=2.32, \mathrm{SD}=.71)$. However, the findings of this study revealed that the mean scores of the academicians at the university were below the mean scores of the normative sample for all transformational subscales. The result described that academic administrators displayed transformational leadership styles less than the normative sample. The study also discovered that the mean scores of the academicians were below the mean scores of the normative sample for all the leadership outcomes factors: extra effort, effectiveness, and satisfaction.
\end{abstract}

\section{Keywords:}

Transformational leadership, extra effort, effectiveness, satisfaction.

\section{INTRODUCTION}

As a developing country in the 21 st century, Malaysia faces many challenges in the era of globalization, and Malaysians must be equipped to confront them. Education is one of a nation's most important institutions in order to develop the human capital of the highest quality and a first-class mentality in Malaysia. However, significant contributions of effort, involvement, and overall educators' professionalism determine the successfulness of educational programs (Krishnaveni \& Anitha, 2007; Noordin \& Jusoff, 2009). In public universities, the commitment of the academicians is related to the satisfaction of the academicians, and healthy university climate (Chen, Yang, Shiau, \& Wang, 2006; Noordin \& Jusoff, 2009). In addition, Fernandez (2008) stated that leadership styles help to predict employees' satisfaction and performance. In higher education institutions, academic leadership positions are held by faculty members such as department chairs, deputy deans, and deans, whose principal activity is administration (Flowers \& Moore, 2008; Siddique, Aslam, Khan, \& Fatima, 2011). Leaders at the faculty or department level are also known as academic administrators, who are normally selected because of their outstanding performance as academicians instead of having leadership or managerial experiences (Bryman, 2007). As they strive to sustain their reputation in research and writings, they may lack attention to various factors of departmental leadership effectiveness (Bryman, 2007). In addition, most of the departmental leaders are temporary appointments among academics. Once they completed their term, departmental leaders will resume their old academic roles. Further, 
Bryman (2007) stated that little empirical research has been conducted focusing on the effectiveness of leadership styles among higher education leaders. Since leadership is a management function that involves interactions to direct, motivate, inspire, and influence others to achieve organizational goals (Mosadeghrad \& Yarmohammadian, 2006; Northouse, 2007; Siddique et al., 2011), the effectiveness of the leadership style of academic leaders is a major determinant of the academicians' commitment, job satisfaction, and performance.

There have been very little research on leadership concepts and theories, and their relationship with other factors such as job satisfaction specific to Malaysian setting that help to evaluate current theories in non-Western cultures (Yiing \& Ahmad, 2009). This statement is supported by Siddique et al. (2011), who delineates that leadership in higher education is not explored widely and has been considered less important, especially in developing countries such as Malaysia. In addition, Fernandez (2008) mentions that most leadership theories and concepts established in private or for-profit firms have not been tested in public organizations. Fernandez also recommends future research test transformational and charismatic leadership in the context of public organizations. Therefore, this study intends to contribute to the existing knowledge of transformational leaderships styles from Malaysian public higher education perspective. The purposes of this study are to investigate the practice of transformational leadership among academic administrators, and to determine the level of leadership outcomes including extra effort, effectiveness, and satisfaction of academicians..

\section{PROBLEM STATEMENT}

The number of private and public higher education institutions in Malaysia had increased over the past few years (Ahsan, Abdullah, Fie, \& Alam, 2009). The university that has become the subject of this study has striven to enhance and strengthen its teaching, learning, and research capabilities and had taken various initiatives to complement its educational excellence. Due to the increasing number of universities and professional employment, the management of universities and academicians have faced many challenges in order to stay competitive (Ahsan et al., 2009; Sabharwal \& Corley, 2009).

Academicians in higher education feel the pressure because of the increase in workloads, higher expectations for research, more demand for external grants, excessive administrative tasks, and the attitude of managers that have shown lack of recognitions and rewards (Waters \& Bardoel, 2006). Therefore, academicians may feel stressful and the issues of satisfaction and retention become more important (Ahsan et al., 2009; Sabharwal \& Corley, 2009). Erkutlu (2008) postulated that an organization should understand the nature of leadership behavior and investigate effective leadership styles, which are appropriate for the managerial level and types of jobs. In addition, an organization should ensure that management's leadership style matches the organizational requirements and take corrective measures, if necessary (Erkutlu, 2008). Similarly, Thacker and Holl (2008) also suggest that research should focus on employees' perceptions of management's leadership styles and behavior in order to ensure employees' satisfaction and the effectiveness of the management functions.

From another perspective, some leadership styles can influence and increase employee motivation, enable employees to experience more positive emotions, reduce the possibility of decreased job satisfaction, and reduce employees' turnover intentions (Bono, Foldes, Vinson, \& Muros, 2007; Wells \& Peachey, 2010; Yulk, 2006). Kouzes and Posner (2007) stated that leadership is a relationship between leaders who inspire their followers. The quality of this 
relationship determines the completion of extraordinary things (Kouzes \& Posner, 2007). Thus, the dynamic of the relationship requires leaders to be aware of the current reality of their followers while focusing on their future possibilities (Fairholm, 2011). Therefore, leaders need to understand their leadership styles and behavior, and learn to match their styles with employees' needs, nature of jobs, and working environment (Northouse, 2007).

\section{LITERATURE REVIEW}

Howell and Costley (2006) define leadership "as a process used by an individual to influence group members toward the achievement of group goals in which the group members view the influence as legitimate" (p. 4). In other words, leadership is described as an influence relationship among leaders and followers towards the achievement of an organizational vision (Daft, 2011; Robbins \& Judge, 2013). Leadership is considered a vital factor in determining the success or failure of an organization (Bass \& Bass, 2008; Long \& Thean, 2011).

Yulk (2006) defines leadership as "the process of influencing others to understand and agree about what needs to be done and how to do it, and the process of facilitating individual and collective efforts to accomplish shared objectives" (p. 8). A leadership style is the leader's concern about how to lead, govern, and guide people in an organization (Bass \& Bass, 1974).

Bass and Bass (1974) explain "transformational leaders motivate their followers to do more than the followers originally intended and thought possible. The leaders set challenging expectations and achieve a higher standard of performance. Transformational leadership looks to a higher purpose" (p. 618). Transformational leadership requires leaders to inspire, motivate, and elevate their subordinates' motivation for significant positive changes while guarding organizational health (Bass \& Bass, 1974; Warrick, 2011). According to Avolio and Bass (2004), there are four key aspects of transformational leadership: idealized influence, inspirational motivation, intellectual stimulation, and individualized consideration.

\section{Idealized influence}

Transformational leaders are models who exhibit high ethical and moral conducts to their followers for employees to admire, respect, and trust (Bass \& Avolio, 1994; Northouse, 2007; Sosik, 2006). In addition, leaders focus more on employees' need and share their risks (Bass \& Avolio, 1994). Therefore, as leaders hold high expectation of employees' performance and ethical conduct, employees support the leader's vision (Sosik, 2006). This will develop strong employees' emotion and leaders' identification (Yulk, 2006). According to Avolio and Bass (2004), leaders who are socially oriented and limit the use of their power, are able to develop their employees with higher level of autonomy, achievement, and performance. Those employees will have full potential and be fully capable to contribute in the achievement of leaders' goals (Avolio \& Bass, 2004).

\section{Inspirational motivation}

Transformational leaders emphasis good team spirit; exhibit enthusiasm, optimism, and commitment; provide meaning and challenge in followers' work; and deliver clear expectations of performance to achieve high levels of success (Bass \& Avolio, 1994; Northouse, 2007; Sosik, 2006). Leaders share organizational visions with employees and 
provide potential ways to achieve the visions (Avolio \& Bass, 2004). As leaders model appropriate behaviors, they empower employees to increase their self-confidence and competency (Sosik, 2006; Yulk, 2006).

\section{Intellectual stimulation}

Transformational leaders stress creativity and innovation among followers by encouraging new approaches in doing things and solving problems (Bass \& Avolio, 1994; Northouse, 2007). Leaders are able to distinguish, grasp, conceptualize, and articulate the organizational strengths, weaknesses, opportunities, and threads moving towards the desired future (Avolio \& Bass, 2004). Transformational leaders practice intellectual stimulation by encouraging employees to re-engineer their work process and rethink unsuitable or outmoded business models (Sosik, 2006). This will require employees to be aware of the problems and view them from new perspectives (Yulk, 2006). Awareness of the problems might encourage employees to question their beliefs, assumptions, values, and inappropriate way of solving current problems in which, in turn, they develop the ability to foresee and solve future problems (Avolio \& Bass, 2004).

\section{Individualized consideration}

Transformational leaders act as mentors by providing special attention to every follower's need for success and growth (Bass \& Avolio, 1994; Northouse, 2007). Transformational leaders who use individualized consideration value the advantages of diversity among the employees and support their different needs, abilities, and goals to develop their full potential (Avolio \& Bass, 2004; Sosik, 2006). Therefore, employees appreciate the personal learning and collaborative work with others that might contribute to the expansion of knowledge, skills, and abilities (Sosik, 2006). Bass and Avolio (1994) stated that in order to develop employees, leaders should delegate and empower them while giving personal mentoring, support, and coaching. In addition, leaders should create supportive organizational culture and provide continuous follow-up and feedback to the employees (Avolio \& Bass, 2004).

\section{RESEARCH METHODOLOGY}

The purpose of this study was to investigate the academic administrators' leadership style at one faculty of a public university in Malaysia. The study was a survey research design. The target population of the study was 71 full-time academicians at the faculty. There were 37 male and 34 female academicians at the faculty. According to Creswell (2008), it is possible to study the entire population in any survey research if the population is small, can be easily identified, and an actual list of population can be compiled. Investigating the entire population is called census study, in which the conclusion can be drawn for total population (Creswell, 2008; Zikmund, Babin, Carr, \& Griffin, 2013).

The MLQ 5X-Short developed by Avolio and Bass (2004) was utilized as an instrument to examine the perception of the respondents toward the academic administrators leadership at the faculty. The researcher obtained permission to use the MLQ 5X-Short from Mind Garden. The MLQ 5X-Short composed of 45 items to measure nine leadership components and the scale used five choices per item ranging from 0 (not at all), 1 (once in a while), 2 (sometimes), 3 (fairly often), to 4 (frequently, if not always). The MLQ 5X-Short included 
self-scoring features used to evaluate respondents' perceptions of leadership style of academic administrators at the faculty. Academic administrators at the faculty were head of the departments, deputy deans, and dean. Respondents were required to rate their immediate leader in terms of transformational leadership style by completing the Rater Form. The Rater Form required respondents to evaluate how often or to what degree their leader displayed certain leadership behaviors.

Collected data were analyzed utilizing SPSS, Version 22. Descriptive analysis described the basic characteristics of the respondents and questions on the instruments. The demographic data of the respondent was summarized using a tabulation and frequency table that included frequencies and percentages. Simple tabulations displayed how frequently responses for each question occurred (Zikmund et al., 2013). Means and standard deviations were used to analyze the level of practice of each transformational leadership components.

\section{RESULTS}

Total respondents of this study involved $44 \%$ male and $56 \%$ female lecturers at the subject university. A summary of the demographic data are shown in Table 1.

Table 1: Demographic characteristics of the respondents

\begin{tabular}{|c|c|c|c|}
\hline Characteristics & Category & Frequency (n) & Percentage $(\%)$ \\
\hline \multirow[t]{2}{*}{ Gender } & Male & 31 & 44.3 \\
\hline & Female & 39 & 55.7 \\
\hline \multirow[t]{3}{*}{ Age } & 30-39 years old & 30 & 42.9 \\
\hline & $40-49$ years old & 22 & 31.4 \\
\hline & 50-years old and above & 18 & 25.7 \\
\hline \multirow[t]{2}{*}{ Marital Status } & Single & 9 & 12.9 \\
\hline & Married & 61 & 87.1 \\
\hline \multirow[t]{2}{*}{ Highest Education Level } & Master's Degree & 19 & 27.1 \\
\hline & Doctorate & 51 & 72.9 \\
\hline \multirow[t]{4}{*}{ Current Position } & Lecturer & 18 & 25.7 \\
\hline & Senior Lecturer & 41 & 58.6 \\
\hline & Associate Professor & 9 & 12.9 \\
\hline & Professor & 2 & 2.8 \\
\hline \multirow[t]{3}{*}{ Years of service in profession } & 6 to 10 years & 17 & 24.3 \\
\hline & 11 to 15 years & 32 & 45.7 \\
\hline & More than 15 years & 21 & 30.0 \\
\hline \multicolumn{4}{|l|}{ Years of service in current } \\
\hline \multirow[t]{4}{*}{ institution } & Less than 5 years & 3 & 4.3 \\
\hline & 6 to 10 years & 21 & 30.0 \\
\hline & 11 to 15 years & 39 & 55.7 \\
\hline & More than 15 years & 7 & 10.0 \\
\hline
\end{tabular}

Most of the respondents (43\%) were from the age of 30 to 39 years old. Eighty-seven percent of the respondents were married and $13 \%$ were single. Majority of the respondents (73\%) indicated a doctorate as the highest education level obtained and 19\% held a master's degree. From the 70 respondents, $59 \%$ were senior lecturers, $24 \%$ lecturers, $13 \%$ associate 
professors, and only 3\% were professors. The majority of the respondents (46\%) had 11 to 15 years of experience in the profession and only $24 \%$ of them had less than 10 years of experience. Most of the respondents (56\%) had been working in the university for 11 to 15 years.

\section{Reliability of the scales}

Coefficient alpha $(\alpha)$ is the most commonly applied estimate of a multiple-item scale's reliability that range between the values of 0 (no consistency) to 1 (complete consistency; Zikmund et al., 2013). Cronbach's $\alpha$ was utilized to assess the reliability of the scales used in this study. According to Zikmund et al. (2013), an $\alpha$ value between 0.80 and 0.95 is considered very good, $\alpha$ value between 0.7 and 0.8 is considered good, $\alpha$ value between 0.6 and 0.7 is considered fair, while $\alpha$ value below 0.6 is considered poor. In this study, Cronbach's $\alpha$ value of each of the 12 scales of the MLQ ranged from .60 to .88, demonstrating good reliability for all scales.

\section{Transformational leadership}

The mean scores of academicians on MLQ were compared with the means and standard deviations for normative samples established by Avolio and Bass (2004). As revealed in Table 2, the mean scores of the academicians at the subject university were below the mean scores of the normative sample for subscales idealized influence (attributed), idealized influence (behavior), inspirational motivation, intellectual stimulation, individual consideration, and contingent reward. The results portrayed that academic administrators exhibited these leadership styles less than the normative sample.

Results in Table 2 also displayed the means scores of the academicians were below the mean scores of the normative sample for all three leadership outcome factors: extra effort, effectiveness, and satisfaction. The mean scores of the academicians was moderately high on extra effort $(\mathrm{M}=2.40, \mathrm{SD}=.80)$, effectiveness $(\mathrm{M}=2.49, \mathrm{SD}=.75)$, and satisfaction $(\mathrm{M}=$ $2.54, \mathrm{SD}=.84)$. This indicated the academicians readily wielded extra effort, perceived their leaders as effective, and were moderately satisfied with their academic administrators. However, the academicians at the university had lower extra effort, perceived their academic administrators less effective, and experienced lower satisfaction than the normative sample.

Table 2: Mean scores on the Multifactor Leadership Questionnaire for academicians $(\mathrm{N}=70)$ and for normative sample $(\mathrm{N}=4,376)$

\begin{tabular}{ccccc}
\hline \multicolumn{1}{c}{ Subscales } & \multicolumn{2}{c}{ Academicians } & \multicolumn{2}{c}{ Normative Sample } \\
& M & SD & M & SD \\
\hline Transformational leadership & 2.42 & .55 & -- & -- \\
Idealized influence (attributed) & 2.42 & .64 & 2.93 & .82 \\
Idealized influence (behavior) & 2.60 & .63 & 2.73 & .76 \\
Inspirational motivation & 2.72 & .60 & 2.97 & .79 \\
Intellectual stimulation & 2.32 & .71 & 2.76 & .75 \\
Individual consideration & 2.05 & .65 & 2.78 & .88 \\
Extra effort & & & & .94 \\
Effectiveness & 2.40 & .80 & 2.78 & .78 \\
Satisfact & 2.49 & .75 & 3.09 & .91 \\
& & & & \\
Note. -- = data were not available in the normative sample & & & & \\
\end{tabular}

Note. $--=$ data were not available in the normative sample 


\section{DISCUSSION AND RECOMMENDATION}

Malaysia achieved $48 \%$ tertiary education enrollment rates in 2012 , which was a $70 \%$ increment in enrollment within a decade, reaching 1.2 million students in higher education institutions (Ministry of Education Malaysia, 2015). Malaysia was ranked 3rd among the Association of Southeast Asian Nations in terms of undergraduates and postgraduates' enrollment after Singapore and Thailand (Ministry of Education Malaysia, 2015). However, the ability and quality of the higher education institutions determined the quality of the graduates they produced (MaJesus \& Mercedes, 2010; Storen \& Aamodt, 2010). Thus, quality leadership among leaders is essential to ensure the quality of the higher education institutions (Basham, 2012). Moreover, effective leadership drives overall organizational success (Otara, 2015).

In the expansion of higher education institutions in Malaysia, academic administrators, including dean, deputy deans, and heads of departments, have been described as the most important administrators at the university because they have direct interaction with academicians, administration staffs and students (Tahir, Abdullah, Ali, \& Daud, 2014). Academic administrators are responsible for managing and developing human resources, programs, faculty, budget and expenses, and efficient and effective day-to-day operations and making decisions (Otara, 2015; Tahir et al., 2014; Sternberg, 2013). They are also responsible for the faculty's performance while aligning, motivating, inspiring, and uplifting faculty members' spirits towards the achievement of the university's shared vision (Tahir et al., 2014). This greater responsibility may become a burden to academic administrators if they do not have sufficient knowledge and skills that leaders should possess. Lack of leadership skills may affect the effectiveness of their leadership (Tahir et al., 2014).

The academicians participated in this study perceived their academic administrators' leadership style as transformational $(\mathrm{M}=2.42, \mathrm{SD}=.55)$. The most practiced leadership style was inspirational motivation $(\mathrm{M}=2.72, \mathrm{SD}=.60)$, followed by idealized influence (behavior) with $\mathrm{M}=2.60, \mathrm{SD}=.63$ and idealized influence (attributed) with $\mathrm{M}=2.42, \mathrm{SD}=.64$. The least frequent of leadership styles that displayed by the academic administrators were individual consideration $(\mathrm{M}=2.05, \mathrm{SD}=.65)$, and intellectual stimulation $(\mathrm{M}=2.32, \mathrm{SD}=$ .71). Although academic administrators of a subject university moderately practiced transformational leadership and all its components, it was still below the practiced of normative sample. This implies that, academic administrators have to continuously improve and frequently exhibit their transformational leadership styles, especially on individual consideration and intellectual stimulation.

The findings of this study supported results of the previous studies whereby leaders frequently demonstrated transformational leadership in an organization (Bronkhorst, Steijn, \& Vermeeren, 2015; Czech \& Forward, 2015; Hamidifar, 2009; Ho, Fie, Ching, \& Ooi, 2009; Menon, 2014; Tahir et al., 2014). Transformational leadership is able to increase the level of subordinates' awareness and value of shared vision and objectives of the organization. It is concerned about subordinates' values and beliefs and inspires them to move to higher levels of needs and ethical behaviors (Czech \& Forward, 2015; Northouse, 2007). Tahir et al. (2014) assert that transformational academic administrators encourage their followers to be creative and innovative and give them the opportunity to develop and improve the faculty.

Very few empirical studies have been conducted on academic administrators' leadership in Malaysian higher educational context (Tahir et al., 2014). The findings of this study provide better insights for university administrators to design effective training for academic administrators. However, the findings of this study cannot be generalized to all academic administrators in Malaysia. The similar study should be conducted in other universities in Malaysia considering all faculties. 


\section{CONCLUSION}

Academic administrators are usually chosen based on their intellect and research abilities, not solely based on leadership knowledge and skills (Tahir et al., 2014). Although leadership styles, skills, and abilities are major contributors to the success of academic administrators, they are appointed without any formal leadership training (Tahir et al., 2014; Sternberg, 2013). Therefore, it is crucial for Malaysian higher education institutions to investigate the effectiveness of academic administrators' leadership at the faculty level. As suggested by Howell and Costley (2006), leadership training can be a key factor in effective leadership. In an organization, management support and member-leader relationships may increase trustworthiness between leaders and members. Further, these can create competent environments and better organizational climate in the university.

\section{References}

Ahsan, N., Abdullah, Z., Fie, D. Y. G. \& Alam, S. S. (2009). A study of job stress on job satisfaction among university staff in Malaysia: Empirical study. European Journal of Social Sciences, $8(1), 121-131$.

Avolio, B. J., \& Bass, B. M. (2004). Multifactor leadership questionnaire: Manual and sampler set (3rd ed.). Redwood City, CA: Mind Garden.

Basham, L. M. (2012). Transformational leadership characteristics necessary for today's leaders in higher education. Journal of International Education Research, 8, 343-348. Retrieved from http://www.cleinstitute.com/

Bass, B. M., \& Bass, R. (1974). The Bass handbook of leadership: Theory, research, and managerial applications (4th ed.). New York, NY: Free Press

Bass, B. M. \& Bass, R. (2008). The Bass handbook of leadership: Theory, research and managerial applications (4th ed.). New York, NY: Free Press.

Bono, J. E., Foldes, H. J., Vinson, G., \& Muros, J. P. (2007). Workplace emotions: The role of supervision and leadership. Journal of Applied Psychology, 92, 1357-1367. doi:10.1037/00219010.92.5.1357

Bronkhorst, B., Steijn, B., \& Vermeeren, B. (2015). Transformational leadership, goal setting, and work motivation: The case of a Dutch municipality. Review of Public Personnel Administration, 35, 124-145. doi:10.1177/0734371X13515486

Bryman, A. (2007). Effective leadership in higher education: A literature review. Studies in Higher Education, 32, 693-710. doi:10.1080/03075070701685114

Chen, S. H., Yang, C. C., Shiau, J. Y., \& Wang, H. H. (2006). The development of employee satisfaction model for higher education. The TQM Magazine, 18(5), 484-500. doi:10.1108/09544780610685467

Cohen, J. W. (1988). Statistical power analysis for the behavioral sciences (2nd ed.). Hillsdale, NJ: Lawrence Erlbaum.

Creswell, J. W. (2008). Educational research: Planning, conducting, and evaluating quantitative and qualitative research (3rd ed.). Upper Saddle River, NJ: Pearson

Czech, K., \& Forward, G. L. (2015). Leadership communication: faculty perceptions of the department chair. Communication Quarterly, 58, 431-457. doi:10.1080/01463373.2010.525158

Daft, R. L. (2011). Leadership (5th ed.). Stanford, CT: Cengage Learning. 
Erkutlu, H. (2008). The impact of transformational leadership on organizational and leadership effectiveness: the Turkish case. Journal of Management Development, 27, 708-726. doi:10.1108/02621710810883616

Fairholm, G. W. (2011). Real leadership: How spiritual values give leadership meaning. Santa Barbara, CA: Praeger.

Fernandez, S. (2008). Examining the effects of leadership behavior on employee perceptions of performance and job satisfaction. Public Performance and Management Review, 32, 175-205. doi:10.2753/PMR1530-9576320201

Flowers, L. A., \& Moore, J. L. III (2008). Unraveling the composition of academic leadership in higher education: Exploring administrative diversity at 2-year and 4-year institutions. Journal of Thought, 43(3), 71-81, 126-127. doi:10.2307/jthought.43.3-4.71

Hamidifar, F. (2009). A study of the relationship between leadership styles and employee job satisfaction at Islamic Azad University branches in Tehran, Iran. AU-GSB-e-Journal, 3(1), 4558.

Ho, J. S. Y., Fie, D. Y. G., Ching, P. W., \& Ooi, K. B. (2009). Relationship between the full-range leadership and insurance salesperson's job satisfaction. International Journal of Business and Management Science, 2(1), 43-60.

Kouzes, J. M., \& Posner, B. Z. (2007). The leadership challenge (4th ed.). San Francisco, CA: John Wiley and Sons.

Krishnaveni, R., \& Anitha, J. (2007). Educators' professional characteristics. Quality Assurance in Education, 15(2), 149-161.

Long, C. S., \& Thean, L. Y. (2011). Relationship between leadership style, job satisfaction and employees' turnover intention: A literature review. Research Journal of Business Management, 5, 91-100. doi:10.3923/rjbm.2011.91.100

MaJesus, F. S., \& Mercedes, T. A. (2010). Competencies of graduates as an indicator of external quality assurance in universities. Regional and Sectoral Economic Studies, 10(3), 77-91.

McShane, S. L., \& Von Glinow, M. A. (2005). Organizational behavior (3rd ed.). New York, NY: McGraw-Hill.

Menon, M. E. (2013). The relationship between transformational leadership, perceived leader effectiveness and teachers' job satisfaction. Journal of Educational Administration, 52, 509528. doi:10.1108/JEA-01-2013-0014.

Ministry of Education Malaysia. (2015). Malaysia education blueprint 2013-2025. Retrieved from http://www.moe.gov.my/en/pelan-pembangunan-pendidikan-malaysia-2013-2025

Mosadeghrad, A. M., \& Yarmohammadian, M. H. (2006). A study of relationship between managers' leadership style and employees' job satisfaction. Leadership in Health Services, 19(2), 11-28. doi:10.1108/13660750610665008

Noordin, F., \& Jusoff, K. (2009). Levels of job satisfaction amongst Malaysian academic staff. Asian Social Science, 5(5), 122-128. doi:10.5539/ass.v5n5p122

Northouse, P. G. (2007). Leadership theory and practice (4th ed.). Thousand Oaks, CA: Sage.

Otara, A. (2015). Academic dean and the challenges of meeting changing expectations within a competitive higher education environment in Africa. Creative Education, 6, 134-143. doi:10.4236/ce.2015.62012

Robbins, S. P., \& Judge, T. A. (2013). Organizational behavior (15th ed.). London, England: Pearson.

Sabharwal, M., \& Corley, E. A. (2009). Faculty job satisfaction across gender and discipline. The Social Science Journal, 46, 539-556. doi:10.1016/j.soscij.2009.04.015 
Siddique, A., Hassan, D. A., Khan, M., \& Fatima, U. (2011). Impact of academic leadership on facultys' motivation, and organizational effectiveness in higher education system. International Journal of Business and Social Science, 2(8), 184-191.

Sosik, J. J. (2006). Full rage leadership: Model, research, extensions, and training. In R. J. Burke \& C. L. Cooper (Eds.), Inspiring leaders (pp. 33-66). New York, NY: Routledge.

Sternberg, R. J. (2013, September). Leadership styles for academic administrators: What works when? Change, 45, 24. Retrieved from ProQuest Journals database. (UMI No. 1678885112)

Storen, L. A., \& Aamodt, P. O. (2010). The quality of higher education and employability of graduates. Quality in Higher Education, 16, 297-313. doi:10.1080/13538322.2010.506726.

Tahir, L., Abdullah, T., Ali, F., \& Daud, K. (2014). Academic transformational leadership: An investigation of heads of department leadership behaviors in Malaysian public universities. Educational Studies, 40, 473-495. doi:10.1080/03055698.2014.932272

Thacker, R. A., \& Holl, K. B. (2008). Behaviorally-based management training: Linking behaviors to employees' satisfaction. Industrial and Commercial Training, 40, 102-108. doi:10.1108/00197850810858947

Warrick, D. D. (2011). The urgent need for skilled transformational leaders: Integrating transformational leadership and organization development. Journal of Leadership, Accountability and Ethics, 8(5), 11-26.

Waters, M. A., \& Bardoel, E. A. (2006). Work-family policies in the context of higher education: Useful or symbolic? Asia Pacific Journal of Human Resources, 44(1), 67-82. doi: $10.1177 / 1038411106061510$

Wells, J. E., \& Peachey, J. W. (2011). Turnover intentions: Do leadership behaviors and satisfaction with the leader matter? Team Performance Management, 17(1/2), 23-40. doi:10.1108/13527591111114693

Yiing, L. H., \& Ahmad, K. Z. (2009). The moderating effects of organizational culture on the relationships between leadership behavior and organizational commitment and between organizational commitment and job satisfaction and performance. Leadership and Organization Development Journal, 30(1), 53-86. doi:10.1108/01437730910927106

Yulk, G. (2006). Leadership in organizations (6th ed.). Upper Saddle River, NJ: Pearson Prentice Hall.

Zikmund, W. G., Babin, B. J., Carr, J. C., \& Griffin, M. (2013). Business research methods (9th ed.). Mason, OH: South-Western. 